\title{
Effect of Spraying Silicon, Selenium and Humic Acid on Fruiting of Early Sweet Grape vines
}

\section{Kh. Uwakiem}

Viticulture Department, Horticulture Research Institute, Agricultural Research Centre, Cairo, Egypt.

\begin{abstract}
T
HIS STUDY was conducted during 2013 and 2014 seasons to elucidate the effect of single and combined applications of humic acid and potassium silicate each at 0.05 to $0.2 \%$ and selenium at $0.025 \%$ to $0.1 \%$ on growth, vine nutritional status, yield and quality of Early Sweet grapevines.
\end{abstract}

Single and combined applications of humic acid and potassium silicate each at 0.05 to $0.2 \%$ and selenium at 0.025 to $0.1 \%$ were very effective in stimulating growth characteristics, vine nutritional status, yield and quality of Early Sweet grapevines relative to the check treatment. Using humic acid, potassium silicate and selenium gave the best results with regard to yield and berry quality. The promotion on these parameters was related to increase the concentration of each compound. Using these compounds together was more effective than using each alone.

To improve yield and berry quality of Early Sweet grapevines grown under Minia region conditions, it is recommended to spray the vines three times at growth start (last week of February.), just after berry setting (Mid of April) and three weeks later ( $1^{\text {st }}$ week of May) with a mixture containing humic acid and potassium silicate each at $0.1 \%$ and selenium at $0.05 \%$.

Keywords: Humic acid, Selenium, Silicon, Early Sweet grapevines.

Many attempts have been carried to find out the best horticultural practices should be applied to improve yield and berry quality of the prime, popular and new introduced grapevine cv. Early Sweet grown under Minia region conditions.

Early sweet is earliest white seedless table grape variety commercially available, ripening at least 7 days before its competitors, and provides good eating quality, slight Muscat flavour, crisp texture and an overall eating quality which add value to its marketability. It has a larger seedless berry with creamy white color.

Abd El-Monem- Eman et al. (2008) Found that using humic acid was accompanied with enhancing the yield of Thompson seedless grapevines. Percentage of N, P and $\mathrm{K}$ in leaf of Flame seedless grapevines and soil fertility were considerably increased in response to application of humic Abd El-Hameed and Ahmed (2010). Vine nutritional status of Superior seedless grapevines was 
remarkably enhanced in response to soil addition of humic acid Abdelaal et al. (2013). Alam (2014) decleared that supplying Superior seedless grapevines with humic acid improved yield and cluster weight. Growth characteristics of Superior seedless grapevines enhanced in response to the application of humic acid partially instead of mineral N fertilizer Abd El- Razek (2014).

Silicon is widely considered as an activator by stimulating the expression of natural defense reaction through the production of phenolic compounds. Epstein \& Bloom (2003) and Al-Wasfy (2013) found that silicon application increased plant pigments as well as nutritional status on Sakkoti date palms.

Selenium has many functions in the active site of a large number of selenium dependent enzymes such as glutathione- peroxidase and as anticancer and other physiological functions. Gupta et al. (2000). It is an important element associated with the enhancement of antioxidant activity in plants, animals and humans Rayman (2002). It also influences the nutrient balance in the plant. Nowak-Barbara (2008).

The target of this study was to examine the effect of silicon, selenium and humic acid on growth, vine nutritional status, yield and quality of Early Sweet grapevines grown under Minia region conditions.

\section{Material and Methods}

This study was carried out during 2013 and 2014 seasons on 117 uniforms in vigour 5- years old Early Sweet grapevines grown in a private vineyard located at West Matay, Matay district, Minia Governorate, Egypt. Vines are spaced at 2x $3 \mathrm{~m}$ apart grown in sandy soil and supported by a Gable system. Soil analys is is found in Table 1. Vines were spur pruning in the first week of January during both seasons leaving 72 eyes/ vine (20 fruiting spurs $x$ three eyes + six replacement spurs $\mathrm{x}$ two eyes). Drip irrigation system was followed. Salinity of irrigation water reached $1000 \mathrm{ppm}$. The selected vines received the recommended horticultural practices.

TABLE 1. Analysis of the soil.

\begin{tabular}{|l|c|}
\hline \multicolumn{1}{|c|}{ Constituents } & Values \\
\hline sand $\%$ & 86.0 \\
\hline Silt $\%$ & 4.6 \\
\hline Clay $\%$ & 9.4 \\
\hline Texture & Sandy \\
\hline $\mathrm{pH}(1: 2.5$ extract $)$ & 7.85 \\
\hline $\mathrm{EC}\left(\mathrm{mmhos}^{\prime} 1 \mathrm{~cm} / 25^{\circ} \mathrm{C}\right)$ & 0.97 \\
\hline $\mathrm{CaCO} \%$ & 4 \\
\hline O.M. $\%$ & 0.22 \\
\hline Total $\mathrm{N} \%$ & 0.03 \\
\hline Available $\mathrm{P}(\mathrm{ppm})$ & 1.1 \\
\hline Available $\mathrm{K}(\mathrm{ammonium}$ acetate, $\mathrm{ppm})$ & 101.0 \\
\hline
\end{tabular}

Egypt. J. Hort. Vol. 42, No.1 (2015) 
This experiment included the following thirteen treatments:

- Control

- K- silicate at $0.05 \%$

- $\mathrm{K}$ - silicate at $0.1 \%$

- K- silicate at $0.2 \%$

- selenium at $0.025 \%$

- selenium at $0.05 \%$

- selenium at $0.1 \%$

- humic acid at $0.05 \%$

- $\quad$ humic acid at $0.1 \%$

- humic acid at $0.2 \%$

- All at the low concentration.

- All at the medium concentration.

- All at the high concentration.

Each treatment was replicated three times, three vines per each. The three compounds Humita $25 \%\left(25 \%\right.$ humic acid $\left.+1 \% \mathrm{~N}+4 \% \mathrm{P}_{2} \mathrm{O}_{5}+6 \% \mathrm{~K}_{2} \mathrm{O}\right)$, potassium silicate $\left(25 \% \mathrm{Si}+10 \% \mathrm{~K}_{2} \mathrm{O}\right)$ and selenium dioxide (selenium 99.9\%) at the prementioned concentrations were sprayed three times at growth start (last week of February), just after berry setting (Mid of April) and three weeks later $\left(1^{\text {st }}\right.$ week of May). Triton B as a wetting agent was added at $0.05 \%$. Spraying was done till runoff. Randomized complete block design was followed.

At the last week of May, during both seasons, growth characteristics, main shoot length, number of leaves, main shoot and leaf area $\left(\mathrm{cm}^{2}\right)$ Ahmed and Morsy, (1999) were measured in ten labeled main shoot/ vine. At winter pruning, weight of one -year old wood $(\mathrm{kg})$ and cane thickness $(\mathrm{cm})$ were recorded. Plant pigments, chlorophyll a \& b and total chlorophylls (mg/ 100 g F.W.) in the leaves Von- Wettstein (1957) and N, P, K, Mg \% (one dry weight basis) Balo et al. (1988) were determined at anthesis time.

At harvest time (Mid. of June). Yield (kg/vine), weight ( $\mathrm{g}$ ) and number of clusters/ vine were recorded, shot berries $\%$, berry weight $(\mathrm{g})$, TSS $\%$, reducing sugars $\%$ and total acidity (as g tartaric acid $100 \mathrm{ml}$ juice) A.O.A.C. (2000) were determined.

Treatment means were compared using new L.S.D. test at $5 \%$ according to Mead et al. (1993).

\section{Vegetative growth}

\section{Results and Discussion}

It is clear from the data in Table 2 that spraying silicon, selenium and humic acid either alone or all in combinations significantly enhanced growth i.e main shoot length, number of leaves/ shoot, leaf area, pruning weight and cane thickness. Humic acid was more effective than the other two compounds. The stimulation of growth was proportional to the increase in the concentration. Higher values were recorded for vines that treated three times with the three 
compounds at the higher concentrations. These results were true during both seasons. Humic acid increase water holding capacity Nijjar (1985), that increase uptake of nutrients which improve growth of grapevine. The findings of Melo et al. (2003), that silicon improved root development and water uptake explained the effect of silicon on enhancing growth of early sweet grapes. These results are in agreement with Gaffney et al. (1996), Gad El-Kareem (2012) and Jakovljevic et al. (2011).

TABLE 2. Effect of spraying silicon, selenium and humic acid on some vegetative growth characters of Early $S$ weet grapevines during 2013 and 2014 seasons .

\begin{tabular}{|c|c|c|c|c|c|c|c|c|c|c|}
\hline \multirow[t]{2}{*}{ Treatment } & \multicolumn{2}{|c|}{$\begin{array}{l}\text { Main shoot } \\
\text { length }(\mathrm{cm})\end{array}$} & \multicolumn{2}{|c|}{$\begin{array}{c}\text { Number of } \\
\text { leaves / } \\
\text { shoot }\end{array}$} & \multicolumn{2}{|c|}{$\begin{array}{l}\text { Leaf area } \\
\qquad\left(\mathrm{cm}^{2}\right)\end{array}$} & \multicolumn{2}{|c|}{$\begin{array}{c}\text { Pruning } \\
\text { wood vine } \\
(\mathrm{kg})\end{array}$} & \multicolumn{2}{|c|}{$\begin{array}{c}\text { Cane } \\
\text { thickness } \\
(\mathrm{cm})\end{array}$} \\
\hline & 2013 & 2014 & 2013 & 2014 & 2013 & 2014 & 2013 & 2014 & 2013 & 2014 \\
\hline Control & 90.5 & 91.0 & 11.0 & 11.0 & 135.0 & 133.0 & 1.41 & 1.42 & 0.99 & 0.97 \\
\hline $\begin{array}{l}\text { K- silicate at } \\
0.05 \%\end{array}$ & 98.0 & 99.5 & 18.0 & 19.0 & 141.0 & 141.9 & 1.67 & 1.75 & 1.19 & 1.47 \\
\hline $\begin{array}{l}\text { K- silicate at } \\
0.1 \%\end{array}$ & 101.0 & 102.5 & 20.0 & 21.0 & 144.0 & 145.0 & 1.75 & 1.83 & 1.25 & 1.23 \\
\hline $\begin{array}{l}\text { K- silicate at } \\
0.2 \%\end{array}$ & 101.6 & 103.1 & 20.0 & 21.0 & 144.8 & 146.0 & 1.76 & 1.84 & 1.26 & 1.24 \\
\hline $\begin{array}{l}\text { Selenium at } \\
0.025 \%\end{array}$ & 92.9 & 94.4 & 13.0 & 14.0 & 136.6 & 137.7 & 1.50 & 1.58 & 1.05 & 1.03 \\
\hline $\begin{array}{l}\text { Selenium at } \\
0.05 \%\end{array}$ & 95.0 & 96.6 & 15.0 & 16.0 & 138.0 & 39.0 & 1.59 & 1.67 & 1.12 & 1.10 \\
\hline \begin{tabular}{|l|} 
Selenium at \\
$0.1 \%$
\end{tabular} & 95.3 & 97.0 & 15.0 & 16.0 & 138.6 & 139.7 & 1.60 & 1.68 & 1.13 & 1.11 \\
\hline $\begin{array}{l}\text { Humic acid } \\
\text { at } 0.05 \%\end{array}$ & 104.0 & 105.5 & 23.0 & 25.0 & 147.0 & 148.0 & 1.84 & 1.92 & 1.31 & 1.29 \\
\hline $\begin{array}{l}\text { Humic acid } \\
\text { at } 0.1 \%\end{array}$ & 106.6 & 108.1 & 26.0 & 27.0 & 150.0 & 151.3 & 1.91 & 2.00 & 1.36 & 1.33 \\
\hline $\begin{array}{l}\text { Humic acid } \\
\text { at } 0.2 \%\end{array}$ & 107.0 & 108.5 & 26.0 & 27.0 & 150.6 & 151.7 & 1.92 & 2.01 & 1.37 & 1.33 \\
\hline $\begin{array}{l}\text { All at low } \\
\text { concent. }\end{array}$ & 111.0 & 112.5 & 28.0 & 30.0 & 155.0 & 156.1 & 2.00 & 2.10 & 1.45 & 1.45 \\
\hline $\begin{array}{l}\text { All at med. } \\
\text { concent. }\end{array}$ & 116.0 & 118.0 & 29.0 & 31.0 & 160.0 & 161.9 & 2.10 & 2.31 & 1.50 & 1.49 \\
\hline $\begin{array}{l}\text { All at high } \\
\text { concent. }\end{array}$ & 116.6 & 118.3 & 29.0 & 31.0 & 160.0 & 162.0 & 2.11 & 2.32 & 1.51 & 1.50 \\
\hline $\begin{array}{l}\text { New L.S.D. } \\
\text { at 5\% }\end{array}$ & 1.5 & 1.6 & 2.0 & 2.0 & 1.4 & 1.4 & 0.06 & 0.07 & 0.04 & 0.04 \\
\hline
\end{tabular}

\section{Chemical composition}

It is clear from the data in Tables $3 \& 4$ that single and combined applications of humic acid and silicon each at 0.05 to $0.2 \%$ and selenium at 0.025 to $0.1 \%$ increased significantly plant pigments (chlorophylls a \& b and total chlorophylls), $\mathrm{N}, \mathrm{P}, \mathrm{K}$ and $\mathrm{Mg}$ contents in leaves compared with control. Humic acid was more effective than silicon and selenium in this respect. Combined applications of these compounds were more effective than the individuals. Higher values were

Egypt. J. Hort. Vol. 42, No.1 (2015) 
recorded for vines received three sprays of a mixture containing the three compounds. Similar results were announced during both seasons. The positive effect of humic, silicon and selenium on chemical composition may be due to that humic increased the availability of most nutrients. Silicon enhanced the biosynthesis and translocation of plant pigment and sugar Nijjar (1985). Whanger (2002) found that selenium enhances the biosynthesis of carbohydrate and proteins. The results were supported by the findings of Abd El-Hameed and Ahmed (2010) on humic acid, Ahmed et al. (2013) and Gad El-Kareem (2012) on silicon and Ibrahiem and Al-Wasfy (2014) on selenium.

TABLE 3. Effect of spraying silicon, selenium and humic acid on plant pigments as well as percentages of $N$ and $P$ in the leaves of Early $S$ weet grapevines during 2013 and 2014 seasons.

\begin{tabular}{|c|c|c|c|c|c|c|c|c|c|c|}
\hline \multirow[t]{2}{*}{ Treatment } & \multicolumn{2}{|c|}{$\begin{array}{c}\text { Chlorophyll } \\
\text { a (mg/ } 1 \text { g } \\
\text { F.W.) }\end{array}$} & \multicolumn{2}{|c|}{$\begin{array}{c}\text { Chlorophyll } \\
\text { b (mg/ } 1 \text { g } \\
\text { F.W.) }\end{array}$} & \multicolumn{2}{|c|}{$\begin{array}{c}\text { Total } \\
\text { chlorophylls } \\
(\mathrm{mg} / 1 \mathrm{~g} \\
\text { F.W. })\end{array}$} & \multicolumn{2}{|c|}{ Leaf N \% } & \multicolumn{2}{|c|}{ Leaf $P \%$} \\
\hline & 2013 & 2014 & 2013 & 2014 & 2013 & 2014 & 2013 & 2014 & 2013 & 2014 \\
\hline Control & 1.05 & 1.11 & 0.41 & 0.39 & 1.46 & 1.50 & 1.61 & 1.57 & 0.17 & 0.16 \\
\hline $\begin{array}{l}\text { K- silicate at } \\
0.05 \%\end{array}$ & 1.32 & 1.38 & 0.64 & 0.65 & 1.96 & 2.03 & 1.95 & 1.98 & 0.25 & 0.26 \\
\hline $\begin{array}{l}\text { K- silicate at } \\
0.1 \%\end{array}$ & 1.42 & 1.49 & 0.71 & 0.72 & 2.13 & 2.21 & 2.05 & 2.08 & 0.27 & 0.28 \\
\hline $\begin{array}{l}\text { K- silicate at } \\
0.2 \%\end{array}$ & 1.43 & 1.50 & 0.72 & 0.73 & 2.15 & 2.23 & 2.06 & 2.10 & 0.28 & 0.28 \\
\hline $\begin{array}{l}\text { Selenium at } \\
0.025 \%\end{array}$ & 1.14 & 1.20 & 0.48 & 0.50 & 1.62 & 1.70 & 1.70 & 1.74 & 0.20 & 0.20 \\
\hline $\begin{array}{l}\text { Selenium at } \\
0.05 \%\end{array}$ & 1.22 & 1.28 & 0.56 & 0.58 & 1.78 & 1.86 & 1.80 & 1.83 & 0.23 & 0.23 \\
\hline $\begin{array}{l}\text { Selenium at } \\
0.1 \%\end{array}$ & 1.23 & 1.29 & 0.57 & 0.59 & 1.80 & 1.88 & 1.81 & 1.84 & 0.23 & 0.24 \\
\hline $\begin{array}{l}\text { Humic acid at } \\
0.05 \%\end{array}$ & 1.51 & 1.60 & 0.80 & 0.81 & 2.31 & 2.41 & 2.17 & 2.21 & 0.31 & 0.32 \\
\hline $\begin{array}{l}\text { Humic acid at } \\
0.1 \%\end{array}$ & 1.61 & 1.70 & 0.86 & 0.87 & 2.47 & 2.57 & 2.27 & 2.31 & 0.34 & 0.35 \\
\hline $\begin{array}{l}\text { Humic acid at } \\
0.2 \%\end{array}$ & 1.62 & 1.71 & 0.87 & 0.88 & 2.49 & 2.59 & 2.28 & 2.32 & 0.35 & 0.35 \\
\hline $\begin{array}{l}\text { All at low } \\
\text { concent. }\end{array}$ & 1.72 & 1.81 & 0.94 & 0.95 & 2.66 & 2.76 & 2.39 & 2.44 & 0.37 & 0.40 \\
\hline $\begin{array}{l}\text { All at med. } \\
\text { concent. }\end{array}$ & 1.83 & 1.92 & 0.99 & 1.00 & 2.82 & 2.92 & 2.50 & 2.52 & 0.40 & 0.43 \\
\hline $\begin{array}{l}\text { All at high } \\
\text { concent. }\end{array}$ & 1.84 & 1.93 & 1.00 & 1.00 & 2.84 & 2.93 & 2.51 & 2.53 & 0.41 & 0.44 \\
\hline $\begin{array}{l}\text { New L.S.D. } \\
\text { at } 5 \%\end{array}$ & 0.07 & 0.07 & 0.05 & 0.06 & 0.06 & 0.06 & 0.07 & 0.07 & 0.02 & 0.03 \\
\hline
\end{tabular}

Yield, cluster weight and number

It is noticed from the data in Table 4 that yield $(\mathrm{kg})$, number of clusters/ vine (specially in the second season) and weight (g.) were significantly increased in response to single and combined applications of humic acid, silicon and selenium rather than the control treatment. The increase was significantly 
associated with increasing concentrations of each compound. Using all the combineds applications was more effective than single applications. Higher yield was recorded when the vines treated three times with humic acid and silicon each at $0.1 \%$ plus selenium at $0.05 \%$. Under such promise treatment, yield per vine reached 13.2 and $16.8 \mathrm{~kg}$ during both seasons, respectively. The control vines produced 11.0 and $11.5 \mathrm{~kg}$ yield during both seasons, respectively. Yield increase reached 20.0 and $46.1 \%$ over control during both seasons, respectively. Yield increase is related to the increase in number of clusters and weight (Table 4). Increase chlorophylls a \& b increase photosynthesis consequently sugar which increase cluster weight (Table 3, 5). Turakainen et al. (2004) and (2006) reported that the accumulation of carbohydrate possibly increased yield. These results are in harmony with Abd El-Monem- Eman et al. (2008), Alam (2014) and Abd El- Razek (2014).

TABLE 4. Effect of spraying silicon, selenium and humic acid on percentages of $K$ and $\mathrm{Mg}$, yield and average cluster weight (g) of Early $\mathrm{S}$ weet grapevines during 2013 and 2014 seasons .

\begin{tabular}{|l|c|c|c|c|c|c|c|c|c|c|}
\hline \multirow{2}{*}{ Treatment } & \multicolumn{2}{|c|}{ Leaf K \% } & \multicolumn{2}{|c|}{ Leaf Mg \% } & \multicolumn{2}{c}{$\begin{array}{c}\text { No. of clusters / } \\
\text { vine }\end{array}$} & \multicolumn{2}{|c|}{ Yield/ vine (kg) } & \multicolumn{2}{|c|}{$\begin{array}{c}\text { Averagecluster } \\
\text { weight (g) }\end{array}$} \\
\cline { 2 - 11 } & $\mathbf{2 0 1 3}$ & $\mathbf{2 0 1 4}$ & $\mathbf{2 0 1 3}$ & $\mathbf{2 0 1 4}$ & $\mathbf{2 0 1 3}$ & $\mathbf{2 0 1 4}$ & $\mathbf{2 0 1 3}$ & $\mathbf{2 0 1 4}$ & $\mathbf{2 0 1 3}$ & $\mathbf{2 0 1 4}$ \\
\hline Control & 1.37 & 1.33 & 0.40 & 0.38 & 22.0 & 23.0 & 11.0 & 11.5 & 501.0 & 501.3 \\
\hline $\begin{array}{l}\text { K- silicate } \\
\text { at 0.05\% }\end{array}$ & 1.60 & 1.61 & 0.57 & 0.60 & 22.0 & 25.0 & 11.9 & 13.6 & 541.0 & 544.0 \\
\hline $\begin{array}{l}\text { K- silicate } \\
\text { at 0.1\% }\end{array}$ & 1.66 & 1.67 & 0.65 & 0.68 & 22.0 & 26.0 & 12.1 & 14.1 & 551.0 & 554.0 \\
\hline $\begin{array}{l}\text { K- silicate } \\
\text { at 0.2\% }\end{array}$ & 1.67 & 1.67 & 0.66 & 0.69 & 22.0 & 26.0 & 12.1 & 14.5 & 552.0 & 556.0 \\
\hline $\begin{array}{l}\text { Selenium } \\
\text { at 0.025\% }\end{array}$ & 1.43 & 1.44 & 0.45 & 0.48 & 22.0 & 24.0 & 11.4 & 12.6 & 520.0 & 525.0 \\
\hline $\begin{array}{l}\text { Selenium } \\
\text { at 0.05\% }\end{array}$ & 1.50 & 1.51 & 0.50 & 0.55 & 22.0 & 25.0 & 11.7 & 13.4 & 530.0 & 535.0 \\
\hline $\begin{array}{l}\text { Selenium } \\
\text { at 0.1\% }\end{array}$ & 1.51 & 1.52 & 0.51 & 0.56 & 22.0 & 25.0 & 11.7 & 13.4 & 531.0 & 536.0 \\
\hline $\begin{array}{l}\text { Humic acid } \\
\text { at 0.05\% }\end{array}$ & 1.75 & 1.78 & 0.71 & 0.73 & 23.0 & 27.0 & 12.9 & 15.3 & 562.0 & 567.0 \\
\hline $\begin{array}{l}\text { Humic acid } \\
\text { at 0.1\% }\end{array}$ & 1.83 & 1.86 & 0.76 & 0.78 & 23.0 & 28.0 & 13.0 & 15.9 & 564.0 & 569.0 \\
\hline $\begin{array}{l}\text { Humic acid } \\
\text { at 0.2\% }\end{array}$ & 1.84 & 1.87 & 0.77 & 0.78 & 23.0 & 28.0 & 13.0 & 16.0 & 565.0 & 570.0 \\
\hline $\begin{array}{l}\text { All at low } \\
\text { concent. }\end{array}$ & 1.92 & 1.96 & 0.82 & 0.86 & 23.0 & 28.0 & 13.1 & 16.1 & 571.0 & 575.0 \\
\hline $\begin{array}{l}\text { All at med. } \\
\text { concent. }\end{array}$ & 1.97 & 2.04 & 0.87 & 0.91 & 23.0 & 29.0 & 13.2 & 16.8 & 575.0 & 580.0 \\
\hline $\begin{array}{l}\text { All at high } \\
\text { concent. }\end{array}$ & 1.98 & 2.05 & 0.88 & 0.91 & 23.0 & 29.0 & 13.2 & 16.8 & 576.0 & 581.0 \\
\hline $\begin{array}{l}\text { New L.S.D. } \\
\text { at 5\% }\end{array}$ & 0.05 & 0.04 & 0.04 & 0.04 & NS & 1.0 & 0.2 & 0.2 & 14.0 & 13.3 \\
\hline
\end{tabular}


EFFECT OF SPRAYING SILICON, SELENIUM AND HUMIC ACID ...

TABLE 5. Effect of spraying silicon, selenium and humic acid on percentage of shot berries some physical and chemical characteristics of the grapes of Early S weet grapevines during 2013 and 2014 seasons.

\begin{tabular}{|l|c|c|c|c|c|c|c|c|c|c|}
\hline \multirow{2}{*}{ Treatment } & \multicolumn{2}{|c|}{$\begin{array}{c}\text { Shot } \\
\text { berries \% }\end{array}$} & \multicolumn{2}{|c|}{$\begin{array}{c}\text { Average } \\
\text { berry } \\
\text { weight (g) }\end{array}$} & \multicolumn{2}{|c|}{ TSS \% } & \multicolumn{2}{|c|}{$\begin{array}{c}\text { Reducing } \\
\text { sugars \% }\end{array}$} & \multicolumn{2}{|c|}{$\begin{array}{c}\text { Total } \\
\text { acidity \% }\end{array}$} \\
\cline { 2 - 12 } & $\mathbf{2 0 1 3}$ & $\mathbf{2 0 1 4}$ & $\mathbf{2 0 1 3}$ & $\mathbf{2 0 1 4}$ & $\mathbf{2 0 1 3}$ & $\mathbf{2 0 1 4}$ & $\mathbf{2 0 1 3}$ & $\mathbf{2 0 1 4}$ & $\mathbf{2 0 1 3}$ & $\mathbf{2 0 1 4}$ \\
\hline Control & 12.0 & 11.3 & 5.00 & 4.95 & 18.0 & 17.7 & 14.9 & 15.0 & 0.720 & 0.708 \\
\hline $\begin{array}{l}\text { K- silicate } \\
\text { at 0.05\% }\end{array}$ & 8.0 & 7.0 & 5.64 & 5.60 & 18.9 & 19.0 & 16.1 & 16.0 & 0.660 & 0.651 \\
\hline $\begin{array}{l}\text { K- silicate } \\
\text { at 0.1\% }\end{array}$ & 7.0 & 6.0 & 5.74 & 5.70 & 19.1 & 19.2 & 16.5 & 16.4 & 0.640 & 0.631 \\
\hline $\begin{array}{l}\text { K- silicate } \\
\text { at 0.2\% }\end{array}$ & 6.9 & 6.0 & 5.75 & 5.70 & 19.2 & 19.3 & 16.6 & 16.5 & 0.639 & 0.630 \\
\hline $\begin{array}{l}\text { Selenium } \\
\text { at 0.025\% }\end{array}$ & 11.2 & 10.1 & 5.20 & 5.14 & 18.3 & 18.4 & 15.3 & 15.2 & 0.700 & 0.691 \\
\hline $\begin{array}{l}\text { Selenium } \\
\text { at 0.05\% }\end{array}$ & 10.0 & 9.0 & 5.50 & 5.46 & 18.5 & 18.6 & 15.7 & 15.6 & 0.681 & 0.672 \\
\hline $\begin{array}{l}\text { Selenium } \\
\text { at 0.1\% }\end{array}$ & 9.9 & 8.8 & 5.52 & 5.47 & 18.6 & 18.7 & 15.8 & 15.7 & 0.680 & 0.671 \\
\hline $\begin{array}{l}\text { Humic acid } \\
\text { at 0.05\% }\end{array}$ & 6.0 & 5.0 & 5.85 & 5.79 & 19.4 & 19.5 & 17.1 & 17.0 & 0.610 & 0.601 \\
\hline $\begin{array}{l}\text { Humic acid } \\
\text { at 0.1\% }\end{array}$ & 5.0 & 4.0 & 5.97 & 5.92 & 19.7 & 19.8 & 17.8 & 17.7 & 0.588 & 0.580 \\
\hline $\begin{array}{l}\text { Humic acid } \\
\text { at 0.2\% }\end{array}$ & 4.9 & 3.8 & 5.98 & 5.93 & 19.8 & 19.9 & 17.9 & 17.8 & 0.587 & 0.578 \\
\hline $\begin{array}{l}\text { All at low } \\
\text { concent. }\end{array}$ & 5.0 & 4.0 & 6.10 & 6.05 & 20.1 & 20.2 & 18.3 & 18.2 & 0.550 & 0.541 \\
\hline $\begin{array}{l}\text { All at med. } \\
\text { concent. }\end{array}$ & 4.0 & 3.0 & 6.21 & 6.16 & 20.3 & 20.4 & 18.6 & 18.5 & 0.520 & 0.511 \\
\hline $\begin{array}{l}\text { All at high } \\
\text { concent. }\end{array}$ & 3.9 & 2.8 & 6.22 & 6.17 & 20.4 & 20.4 & 18.7 & 18.5 & 0.519 & 0.510 \\
\hline $\begin{array}{l}\text { New L.S.D. } \\
\text { at 5\% }\end{array}$ & 0.7 & 0.8 & 0.11 & 0.12 & 0.2 & 0.2 & 0.2 & 0.2 & 0.018 & 0.016 \\
\hline
\end{tabular}

\section{Shot berries}

It is worth mentioning that percentage of shot berries was significantly decreased in response to treating the vines three times with humic acid and silicon each at 0.05 to $0.2 \%$ as well as selenium at $0.025 \%$ to $0.05 \%$ comparing to the control treatment. There was a gradual reduction on such undesirable phenomenon with increasing concentrations of these compounds. Significant differences on such characteristics were observed among all concentrations of the three compounds. Combined applications were more effective than individual applications. The lowest values were obtained of clusters harvested from the vines received three sprays of the investigated mixture. Untreated vines produced the highest percentage of shot berries. The results were true during both seasons. The 
effect of humic acid on decreasing shot berries can be explained by its effect on increasing natural hormones, enzyme activity Nijjar (1985).

\section{Berry quality}

Data in Table 5 reveal those single and combined applications of humic acid and silicon each at 0.05 to $0.2 \%$ as well as selenium at 0.025 to $0.1 \%$ significantly increased berry quality in terms of berry weight, TSS $\%$, reducing sugars $\%$ and decreased total acidity $\%$ relative to the control. The promotion on quality of the berries was significantly associated with increasing concentrations of each compound. Raising concentration of each material from the medium to higher one failed to show significant effect on these quality parameters. The best results with regard to quality of the berries were obtained when the vines were treated three times with a mixture of humic acid and silicon each at $0.1 \%$ besides selenium at $0.05 \%$. Untreated vines produced unfavourable effects on fruit quality. These results were true during both seasons. Humic, silicon and selenium improved berry quality through increasing chlorophylls a \& b (Table 3), TSS and reducing sugar (Table 5) that explain their effect on improving berry quality. Nijjar (1985), pointed out that silicon enhances biosynthesis and translocation of plant pigment and sugar. These results are in agreement with Alvarez and Datnoff (2001), on silicon and Jakovljevic et al. (2011), on selenium.

\section{Conclusion}

Treating Early Sweet grapevines grown under Minia region conditions three times at growth start, just after berry setting and 21 days later with a mixture of humic acid and potassium silicate each at $0.1 \%$ besides selenium at $0.05 \%$ gave the best results with regard to yield and berry quality.

\section{References}

Abdelaal, A. H. M., Ahmed, F.F., Ebrahiem, M.E. and Abdel-Kareem, A.M. (2013) The beneficial effects of some humic acid, EM, and weed control treatments on fruiting of Superior seedless grapevines. Stem. Cell., 4 (3), 258-268.

Abd El- Hameed, H.M. and Ahmed, A.M. (2010) Improving soil fertility and productivity of Flame seedless grapevines grown under sandy soil condition by application of humic acid. Minia J. of Agric. Res. Develop. و30, 31-50.

Abd El-Monem, Eman A.A., Saleh, M.M.S. and Mostafa, E.A.Mj (2008) Minimizing the quantity of mineral $\mathrm{N}$ fertilizers on grapevine by using humic acid, organic and biofertilizers. Res. J. Agric. Bio. Sci., 4 (1), 46-50.

Abd El-Razek, M.A.A. (2014) Influence of replacing a part of mineral $\mathrm{N}$ fertilizer with some organic manure enriched with Spirulina plantensis algae on fruiting of Superior grapevines. M.Sc. Thesis, Fac. Agric., Minia Univ. Egypt.

Egypt. J. Hort. Vol. 42, No.1 (2015) 
Ahmed, F.F. and Morsy, M.H. (1999) A new method for measuring leaf area in different fruit species. Minia. J., Agric. Res. Dev., 19, 97-105.

Ahmed, M. K., Abdelaal, A.H. and Mona M. M. Oraby (2013) Using silicon for increasing the tolerance of mango cv. Ewaise transplants to drought. World Rural Observations, 5 (2), 36-40.

Alam, H.M.M. (2014) Productive capacity of Superior grapevines in relation to application of some slow release fertilizers, effective microorganisms and humic acid. Ph.D. Thesis, Fac. Agric., Minia Univ. Egypt.

Alvarez, J. and Datnoff, L.F. (2001) The economic potential of silicon for integrated management and sustainable rice production. Crop. Prot., 20, 43-48.

Al-Wasfy, M.M. (2013) Response of Sakkoti date palms to foliar application of royal jelly, silicon and vitamins B. J. Amer. Sci., 9 (5), 315-321.

A.O.A.C. (2000) Association of Official Agricultural Chemists $16^{\text {th }}$ ed., Benjamin Franklin Station, Washington, D.C., U.S.A. pp. 490-510.

Balo, E., Prilesszky, G., Happ, I., Kaholami, M. and Vega, L. (1988) Soil improvement and the use of leaf analysis for forecasting nutrient requirements of grapes. Potash Review (Subject 9, $2^{\text {nd }}$ suite, No. 61: 1-5).

Epstein, E. and Bloom, A.J. (2003) Mineral Nutrition of Plant, Principles and Perspectives, $2^{\text {nd }}$ ed. John Wiley \& Sons, New York pp. 1-120.

Gad El-Kareem, M.R. (2012) Improving productivity of Taimour mango trees by using glutathione, silicon and vitamins B. Minia J. Agric. Res. \& Develop., 32 (2), 161-180.

Gaffney, I. S., Marley, N. A. and Clark, S. S. (1996) Humic and fulvic acids isolation, structure and environmental role. Amer. Chemical Soc. Symp. Series p. 65.

Gupta, U.C., Gupta, S.C. and Gupta, M.D. (2000) Selenium in soils and crops, its deficiencies in livestock and humans, implication for management. Commun. Soil Sci. Plant Anal., 31,1791-1807.

Ibrahiem, H.I.M. and Al- Wasfy, M.M. (2014) The promotive impact of using silicon and selenium with potassium and boron on fruiting of Valencia orange trees grown under Minia region conditions. World Rural Observations. 6 (2), 28-36.

Jakovljevic, M., Licina, V., Antic- Mladenov, S. and Velickovic, M. (2011) The effects of selenium application on replant soil and its content in apple leaves and fruits. IV Inter. Sym. on Replant Problems P.I. Acta Hort., 477. 
Mead, R., Currow, R.N. and Harted, A.M. (1993) "Statistical Methods in Agriculture and Experimental Biology", ${ }^{\text {nd }}$ ed., Chapman \& Hall London, pp 10 - 44.

Melo, S. P., Korndorfer, G.H., Korndorfer,C.M., Lana, R.M.Q. and Santan, D.G. (2003) Silicon accumulation and water deficit tolerance in grasses. Scientia Agricola, 60, 755-759.

Nijjar, G. S. (1985) Nutrition of Fruit Trees. Published by Mrs Usha Raj Kumar for kaly ani. New Delhi, pp. 283-302.

Nowak Barbara, H. (2008) Effect of selenium on selected macronutrients in maize plants. J. Elemental, 13 (4), 513-519.

Rayman, M.P. (2002) The argument for increasing selenium intake. Proceeding of the Nutrition Soc., 61, 203-215.

Turakainen, M., Hartikainen, H. and Sepanen, M. (2004) Effect of selenium treatments on potato (Solanum luberosum L.) growth concentration of soluble sugars and starch. J. Agric. and Food Chemistry, 52 and 53 (78), 2382.

Turakainen, M., Hartikainen, H., Ekholm, P. and Seppanen, M.M. (2006) Distribution of selenium in different biochemical fractions and raw darkening degree of potato (Solanum luberosum L.) tubers supplemented with selenate. J. of Agricultural and Food Chemistry, 54, 8617-8622.

Von- Wettstein, D.V.C. (1957). Clatale und der Sumbmikro Skopisne Formwechsel de Plastids. Experimental Cell Research, 12,427.

Whanger, P.D. (2002) Selenium pounds in plants and animal and their biological significance. J. of the Amer. College and Nutrition, 21,223-232.

(Received 25/9/2014;

accepted 28/1/2015) 
EFFECT OF SPRAYING SILICON, SELENIUM AND HUMIC ACID ...

$$
\begin{aligned}
& \text { تأثير رش السيليكون والسيلينيوم وحامض الهيوميك على الإثمار }
\end{aligned}
$$

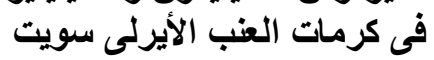

$$
\begin{aligned}
& \text { ماهر خيرى يواقيم }
\end{aligned}
$$

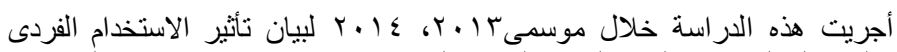

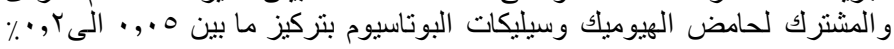

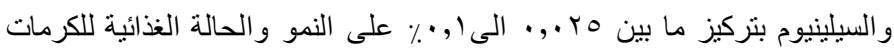

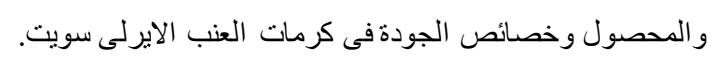

كان الرش الفردى و المشترك لحامض الهيوميك وسيليكات البوتاسيوم

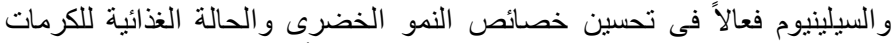

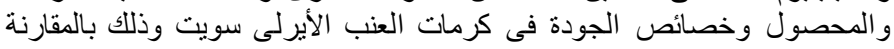

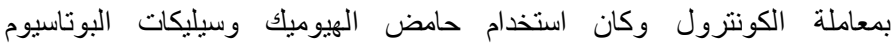

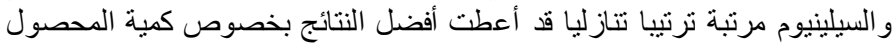

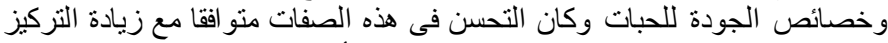

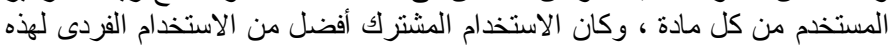
المو اد فى هذا الصدد.

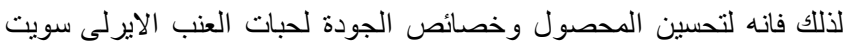

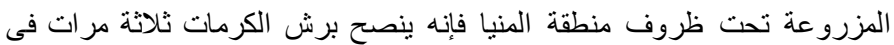

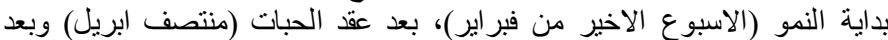

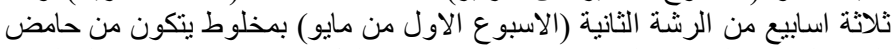

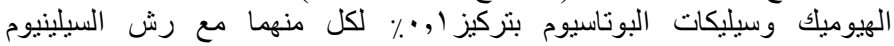
بتركيز ه. 